\title{
HUBUNGAN STATUS PERKAWINAN, APOE \&4, DAN JENIS AKTIVITAS FISIK TERHADAP PENURUNAN KOGNITIF PADA LANSIA PEREMPUAN
}

\author{
RELATIONSHIP OF MARITAL STATUS, APOE \&4, AND TYPES OF PHYSICAL \\ ACTIVITIES ON COGNITIVE DECLINE IN ELDERLY WOMEN
}

Nicholas Andrian Singgih, * Yuda Turana, * Yvonne Suzy Handajani, * Nelly Tina Widjaja, * Linda Suryakusuma*

\section{ABSTRACT}

Introduction: The number of elderly population in Indonesia continues to increase every year, especially women. Elderly women are at higher risk of experiencing decreased cognitive function.

Aims: To determine the relationship between the characteristics of the subject, vascular risk factors, APOE $\varepsilon 4$ genotype, and the type of physical activity with the decline of cognitive function in elderly women.

Methods: A cognitive cohort study of 114 elderly women who had been observed for a mean of \pm 2.5 years, as part of the Active Aging study at Atma Jaya Catholic University. The independent variables of this study included were age, education, marital status, vascular risk factors (hypertension, diabetes, dyslipidemia, and BMI), APOE 84 , and types of physical activity. Cognitive function is measured using Mini Mental State Examination (MMSE).

Results: There were 114 subjects with mean age was $71.22 \pm 7.297$ and $33.3 \%$ experienced a decline in cognitive function. There were 114 subjects with mean age was $71.22 \pm 7.297$ and $33.3 \%$ experienced a decline in cognitive function. Age, marital status (single), and type of physical activity (cooking) have a significant relationship with relative risk (RR) of 4,$45 ; 0,12$; and 0,334 .

Discussions: Factors related to cognitive decline in elderly women were age. Marital status (single) and cooking activities were protective factors.

Keywords: APOE, cognitive decline, elderly, marital status, physical activity

\section{ABSTRAK}

Pendahuluan: Angka populasi lansia di Indonesia setiap tahunnya terus meningkat, terutama perempuan. Lansia perempuan berisiko lebih tinggi mengalami penurunan fungsi kognitif.

Tujuan: Mengetahui hubungan antara karakteristik subjek, faktor risiko vaskular, genotipe APOE $\varepsilon 4$, dan jenis aktivitas fisik terhadap penurunan fungsi kognitif pada lansia perempuan.

Metode: Penelitian kohort terhadap 114 lansia perempuan $>60$ tahun yang diikuti fungsi kognitifnya selama rerata $\pm 2,5$ tahun, sebagai bagian dari penelitian Active Aging di Universitas Katolik Atma Jaya. Variabel bebas penelitian ini meliputi usia, pendidikan, status perkawinan, faktor risiko vaskular (hipertensi, diabetes, dislipidemia, dan IMT), APOE $\varepsilon 4$, dan jenis aktivitas fisik. Fungsi kognitif diukur menggunakan Mini Mental State Examination (MMSE).

Hasil: Didapatkan 114 subjek dengan rerata usia 71,2 $\pm 7,3$ dan 33,3\% mengalami penurunan fungsi kognitif. Analisis multivariat menunjukkan usia, status perkawinan (single), dan jenis aktivitas fisik (memasak) memiliki hubungan bermakna dengan risiko relatif (RR) masing-masing 4,46; 0,12; dan 0,334.

Diskusi: Faktor risiko gangguan fungsi kognitif pada lansia perempuan adalah usia. Status perkawinan (single) dan aktivitas memasak merupakan faktor protektif.

Kata kunci: Aktivitas fisik, APOE, lanjut usia, penurunan kognitif, status perkawinan

*Fakultas Kedokteran dan Ilmu Kesehatan Unika Atma Jaya, Jakarta. Korespondensi: yudamd@yahoo.com.

\section{PENDAHULUAN}

Angka populasi lansia $>60$ tahun di Indonesia terus meningkat setiap tahunnya, yaitu $8,1 \%$ pada tahun 2015 menjadi 9,03\% pada tahun 2017, dan diperkirakan meningkat menjadi $11,1 \%$ pada tahun 2025. Adapun menurut jenis kelamin pada tahun 2017, lansia perempuan memiliki jumlah yang lebih banyak $(9,53 \%)$ dibandingkan laki-laki $(8,54 \%) .{ }^{1}$ Hal ini dapat meningkatkan risiko penurunan fungsi kognitif pada lansia perempuan. Penurunan fungsi kognitif merupakan masalah kesehatan yang dapat menurunkan kemandirian dalam aktivitas sehari-hari pada lansia.

Penelitian di Cina menunjukkan lansia perempuan lebih berisiko mengalami penurunan fungsi kognitif dibandingkan laki-laki. ${ }^{2}$ Sampai saat ini masih sedikit penelitian yang membahas faktor yang paling berpengaruh terhadap penurunan fungsi kognitif pada lansia perempuan. 
Berdasarkan hal tersebut, maka peneliti tertarik untuk melakukan penelitian mengenai hubungan antara karakteristik subjek, penyakit vaskular, genotipe APOE $\varepsilon 4$, dan jenis aktivitas fisik terhadap penurunan fungsi kognitif pada lansia perempuan.

\section{TUJUAN}

Mengetahui hubungan antara karakteristik subjek, penyakit vaskular, genotipe APOE $\varepsilon 4$, dan jenis aktivitas fisik terhadap penurunan fungsi kognitif pada lansia perempuan.

\section{METODE}

Penelitian ini merupakan bagian dari penelitian Active Ageing di Universitas Katolik Atma Jaya, Jakarta, suatu studi kohort yang pertama dilakukan pada tahun 2011 hingga 2015. Pemeriksaan kedua dilakukan pada tahun 2017 dengan rata-rata follow up $\pm 2,5$ tahun, berlokasi di Ruang Publik Terpadu Ramah Anak (RPTRA) Kenanga dan Pusaka 41, didapatkan subjek sebanyak 114 orang. Kriteria inklusi adalah lansia perempuan dan dapat berkomunikasi, serta bersedia mengikuti penelitian. Kriteria eksklusi: tidak bisa membaca dan menulis.

Dilakukan wawancara menggunakan kuesioner untuk menilai usia, pendidikan, status perkawinan, dan jenis aktivitas fisik, serta penilaian hipertensi dan obesitas. Subjek dinyatakan obesitas jika indeks massa tubuh (IMT) $\geq 25 \mathrm{~kg} / \mathrm{m}^{2}$.

Penilaian pada diabetes, dislipidemia, dan genotipe APOE $\varepsilon 4$ berdasarkan pemeriksaan laboratorium. Subjek dinyatakan diabetes jika (gula darah puasa $\geq 126 \mathrm{mg} / \mathrm{dL}$ ), dislipidemia (total kolestrol $\geq 200 \mathrm{mg} / \mathrm{dL} / \mathrm{LDL} \quad \geq 100 \mathrm{mg} / \mathrm{dL} / \mathrm{TGA} \quad \geq 150 \mathrm{mg} / \mathrm{dL} /$ HDL $<40 \mathrm{mg} / \mathrm{dL}$ ), dan APOE $\varepsilon 4+$ jika terdapat $\varepsilon 4$ alel $(\varepsilon 2 / \varepsilon 4 ; \varepsilon 3 / \varepsilon 4 ; \varepsilon 4 / \varepsilon 4)$.

Pengukuran fungsi kognitif menggunakan Mini Mental State Examination (MMSE) untuk menilai fungsi kognitif global pada pemeriksaan pertama dan kedua. Penilaian ini terdiri dari orientasi, registrasi, atensi/kalkulasi, memori, bahasa, dan konstruksi dengan total skor $30 .{ }^{3}$ Fungsi kognitif dinyatakan menurun jika terdapat penurunan 2 poin atau lebih dalam skor MMSE dari pemeriksaan pertama sampai pemeriksaan kedua.
Tabel 1. Karakteristik Subjek $(n=114)$

\begin{tabular}{|c|c|}
\hline Variabel & n (\%) \\
\hline Usia & \\
\hline $\begin{array}{l}-<70 \text { tahun } \\
-\geq 70 \text { tahun }\end{array}$ & $\begin{array}{l}51(44,7 \%) \\
63(55,3 \%)\end{array}$ \\
\hline \multicolumn{2}{|l|}{ Status Pendidikan } \\
\hline - $<9$ tahun & $52(45,6 \%)$ \\
\hline - $\geq 9$ tahun & $62(54,4 \%)$ \\
\hline $\begin{array}{l}\text { Status Perkawinan } \\
\text { - Single/cerai/janda }\end{array}$ & $90(78,9 \%)$ \\
\hline - Sudah menikah & $24(21,1 \%)$ \\
\hline \multicolumn{2}{|l|}{ Hipertensi } \\
\hline - Ya & $56(49,1 \%)$ \\
\hline - Tidak & $58(50,9 \%)$ \\
\hline \multicolumn{2}{|l|}{ Diabetes } \\
\hline - Ya & $18(15,8 \%)$ \\
\hline - Tidak & $96(84,2 \%)$ \\
\hline \multicolumn{2}{|l|}{ Dislipidemia } \\
\hline - Ya & $102(89,5 \%)$ \\
\hline - Tidak & $12(10,5 \%)$ \\
\hline \multicolumn{2}{|l|}{ Obesitas } \\
\hline - Ya & $55(48,2 \%)$ \\
\hline - Tidak & $59(51,8 \%)$ \\
\hline \multicolumn{2}{|l|}{ APOE $\varepsilon 4 *$} \\
\hline - Positif & $30(33,3 \%)$ \\
\hline - Negatif & $60(66,7 \%)$ \\
\hline \multicolumn{2}{|l|}{ Gangguan Kognitif } \\
\hline - Ya & $38(33,3 \%)$ \\
\hline - Tidak & $76(66,7 \%)$ \\
\hline \multicolumn{2}{|c|}{ Jumlah Aktivitas Fisik } \\
\hline$\bullet<5$ & $35(30,7 \%)$ \\
\hline$\bullet \geq 5$ & $79(69,3 \%)$ \\
\hline
\end{tabular}

*Data tidak lengkap; APOE $\varepsilon 4$ : apolipoprotein E4; MMSE: Mini Mental State Examination.

Tabel 2. Distribusi Subjek Berdasarkan Aktivitas Fisik (n=114)

\begin{tabular}{lc}
\hline \multicolumn{1}{c}{ Jenis Aktivitas Fisik } & n (\%) \\
\hline - Menjaga cucu & $53(46,5 \%)$ \\
- Memasak & $85(74,6 \%)$ \\
- Membersihkan rumah & $90(78,9 \%)$ \\
- Mencuci piring & $95(83,3 \%)$ \\
- Menjahit & $42(36,8 \%)$ \\
- Mencuci/menyetrika baju & $77(67,5 \%)$ \\
- Belanja & $105(92,1 \%)$ \\
- Berkebun & $43(37,7 \%)$ \\
\hline
\end{tabular}

Penelitian ini telah mendapat persetujuan etik dari Komisi Etika Penelitian Fakultas Kedokteran Universitas Katolik Atma Jaya dengan nomor 05/02/ KEP-FKUAJ/2018. Penyajian dan analisis data 
Tabel 3. Hubungan antara Sosiodemografi, Klinis, dan Aktivitas Fisik terhadap Fungsi Kognitif (n=114)

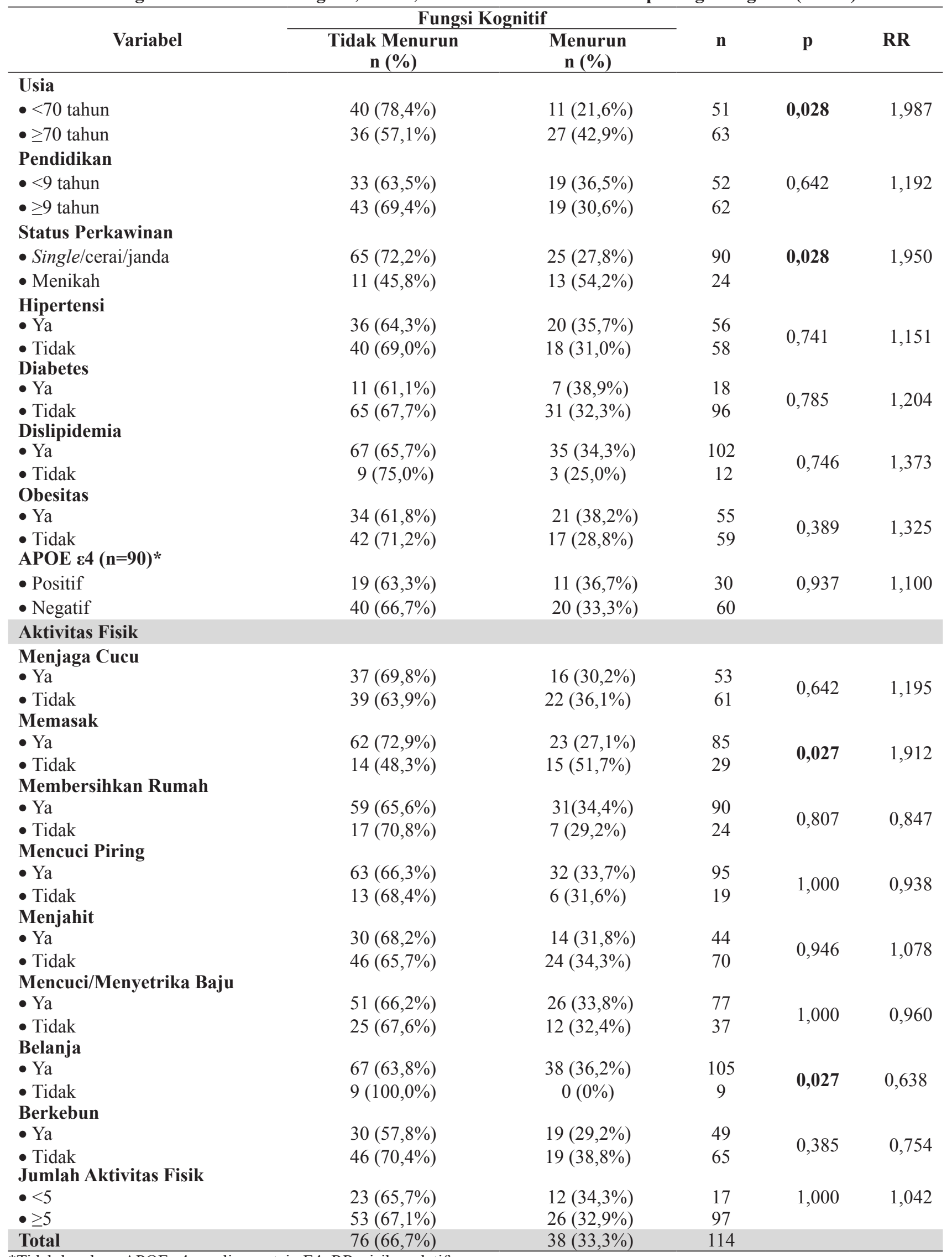

*Tidak lengkap; APOE $\varepsilon 4$ : apolipoprotein E4; RR: risiko relatif. 
menggunakan program SPSS. Analisis data meliputi statistik univariat, bivariat, dan multivariat. Analisis univariat bertujuan untuk melihat gambaran seluruh data penelitian. Analisis bivariat menggunakan Chisquare untuk melihat hubungan antara variabel bebas dengan variabel terikat. Hasil analisis dinyatakan bermakna bila didapatkan $p<0,05$. Analisis multivariat menggunakan regresi logistik untuk menguji variabel dari faktor yang berpengaruh terhadap penurunan fungsi kognitif pada lansia perempuan.

\section{HASIL}

Berdasarkan tabel distribusi (Tabel 1), lebih dari separuh lansia perempuan berusia $\geq 70$ tahun, berpendidikan $\geq 9$ tahun, dan berstatus single/cerai/ janda. Sebanyak 51\% subjek menderita hipertensi, diabetes $(15,8 \%)$, dislipidemia $(89,5 \%)$, obesitas $(48,2 \%)$, mempunyai genotipe APOE $\varepsilon 4(33,3 \%)$, dan mengalami penurunan fungsi kognitif $(33,3 \%)$. Mayoritas subjek melakukan aktivitas fisik $\geq 5$ jenis, terutama kegiatan berbelanja (Tabel 2).

Pada analisis bivariat, didapatkan hanya faktor usia $\geq 70$ tahun, status perkawinan, dan jenis aktivitas fisik (memasak dan belanja) yang memiliki hubungan bermakna dengan penurunan fungsi kognitif (Tabel $3)$.

Analisis multivariat (Tabel 4) menunjukkan faktor yang berisiko menyebabkan penurunan fungsi kognitif adalah usia. Status perkawinan single dan aktivitas memasak bersifat protektif. Variabel belanja tidak memiliki hubungan signifikan pada analisis multivariat.

Tabel 4. Analisis Multivariat Menggunakan Regresi Logistik

\begin{tabular}{lcccc}
\hline \multirow{2}{*}{ Variabel } & \multirow{2}{*}{$\mathbf{p}$} & RR & \multicolumn{2}{c}{ IK 95\% } \\
\cline { 4 - 5 } & & & Bawah & Atas \\
\hline Usia & 0,006 & 4,459 & 1,521 & 13,072 \\
Status perkawinan & 0,001 & 0,127 & 0,038 & 0,417 \\
Memasak & 0,031 & 0,334 & 0,124 & 0,906 \\
Belanja & 0,999 & 0,000 & 0,000 & - \\
\hline
\end{tabular}

RR: risiko relatif; IK: interval kepercayaan.

\section{PEMBAHASAN}

Pada penelitian ini, faktor usia memiliki hubungan yang bermakna terhadap fungsi kognitif. Hal ini sesuai dengan penelitian Shi dkk terhadap
626 individu yang berusia $\geq 80$ tahun, bahwa terdapat hubungan yang bermakna antara usia dan fungsi kognitif $(p<0,005) .{ }^{4}$ Bertambahnya usia akan terjadi penurunan fungsi fisiologis seseorang yang berdampak mengurangi manfaat hormon estrogen, sehingga mengakibatkan penurunan fungsi kognitif pada lansia perempuan. ${ }^{5}$

Faktor pendidikan pada penelitian ini tidak memiliki hubungan yang bermakna terhadap fungsi kognitif. Hal ini berbeda dengan Ren dkk yang melakukan penelitian potong lintang terhadap 1.171 subjek di Cina, bahwa terdapat hubungan bermakna tingkat pendidikan dengan fungsi kognitif. ${ }^{6}$ Paparan pendidikan yang lebih lama diketahui dapat meningkatkan cadangan kognitif melalui neuroplastisitas dan pembentukan jaringan saraf yang lebih kompleks, sehingga menghasilkan kemampuan untuk mengimbangi tingkat neuropatologi yang lebih besar di kemudian hari. ${ }^{7}$

Penelitian ini mendapatkan status perkawinan memiliki hubungan yang bermakna terhadap fungsi kognitif. Individu dengan status perkawinan single/bercerai/janda bersifat protektif terhadap penurunan fungsi kognitif. Hal ini sesuai dengan studi Sommerlad A dkk, bahwa orang berstatus single memiliki risiko rendah gangguan kognitif. Hal ini disebabkan karena keterlibatan usia, jenis kelamin, pendidikan dan kesehatan fisik sehingga memengaruhi fungsi kognitif. Selain itu, individu janda memiliki risiko rendah gangguan kognitif pada penelitian kohort daripada cross-sectional atau case control. ${ }^{8}$ Pada penelitian ini jumlah kelompok single/cerai/janda jauh lebih banyak (hampir 80\%) dibandingkan dengan kelompok menikah/masih ada pasangan, sehingga perlu penelitian lebih lanjut.

Faktor hipertensi pada penelitian ini tidak memiliki hubungan yang bermakna terhadap fungsi kognitif. Hubungan hipertensi dengan fungsi kognitif saat ini masih kontroversial. Beberapa studi menunjukkan penyakit vaskular diketahui sebagai faktor risiko gangguan fungsi kogntif pada beberapa penelitian, tetapi tidak pada semua penelitian. . $^{9-12}$

Pada penelitian ini tidak terdapat hubungan bermakna antara diabetes dan fungsi kognitif. Beberapa penelitian menunjukkan hubungan antara 
diabetes dengan penurunan fungsi kognitif. ${ }^{13}$ Namun Penelitian Zulkifly dkk menggunakan Addenbrooke's Cognitive Examination Revised (ACE-R) menunjukkan tidak terdapat hubungan bermakna antara diabetes dengan gangguan fungsi kognitif. ${ }^{8}$ Penyebab diabetes dan fungsi kognitif tidak berhubungan pada penelitian ini dapat disebabkan follow up fungsi kognitif yang singkat $\pm 2,5$ tahun serta tidak diketahuinya durasi penyakit dan konsumsi obat diabetes.

Pada penelitian ini tidak memiliki hubungan yang bermakna antara faktor dislipidemia dengan fungsi kognitif. Hal ini sesuai dengan penelitian kohort pada 15.792 subjek oleh Gottesman dkk bahwa tidak terdapat hubungan antara kolesterol tinggi terhadap fungsi kognitif. ${ }^{14}$ Kadar LDL yang tinggi merupakan faktor risiko vaskular, namun hubungannya dengan gangguan kognitif masih belum jelas. Penelitian Yasuno dkk menunjukkan tidak adanya hubungan antara LDL, trigliserida, dan kolesterol total dengan skor kognitif. ${ }^{15}$ Tidak adanya hubungan kolesterol dengan gangguan kognitif ringan tipe amnestik juga didukung oleh penelitian Elias dkk yang menunjukkan kadar kolesterol total tidak berhubungan pada ranah memori. ${ }^{16}$ Hal ini menunjukkan bahwa dislipidemia tidak menunjukkan hubungan dengan fungsi kognitif secara global, namun studi Anggara dkk menunjukkan bahwa hiperkolesterolemia lebih berhubungan dengan fungsi bahasa. ${ }^{17}$

Faktor obesitas tidak memiliki hubungan yang bermakna terhadap fungsi kognitif pada penelitian ini. Hal ini sesuai dengan penelitian Ren dkk. ${ }^{6}$ Hubungan obesitas dengan penurunan fungsi kognitif pada lansia saat ini masih kontroversial. ${ }^{18}$ Studi Gustafson dkk yang menyatakan bahwa peningkatan adiposit berkorelasi dengan penurunan volume di sejumlah daerah otak, dalam studinya diketahui bahwa wanita dengan atrofi lobus temporal ditemukan memiliki BMI lebih tinggi, dengan risiko atrofi temporal meningkat $13-16 \%$ per $1 \mathrm{~kg} / \mathrm{m} 2$ kenaikan BMI. ${ }^{19}$

Pada penelitian ini tidak didapatkan hubungan antara faktor APOE $\varepsilon 4$ dengan fungsi kognitif. Sampai saat ini hubungan APOE $\varepsilon 4$ terhadap fungsi kognitif masih kontroversial. Beberapa menunjukkan peningkatan risiko penurunan kognitif dalam hubungan dengan status alel, dan beberapa tidak menunjukkan hubungan..$^{20-23}$

Faktor jenis aktivitas fisik (memasak) memiliki hubungan yang bermakna terhadap fungsi kognitif. Penelitian kami sejalan dengan studi Shalim dkk yang menunjukkan bahwa memasak berhubungan dengan fungsi kognitif. ${ }^{24}$ Aktivitas memasak diteliti memiliki beberapa aspek penting dalam fungsi kognitif. Cerasa dkk menyatakan bahwa memasak memiliki keuntungan dalam memori prospektif dan kinerja perencanaan yang lebih baik, serta melatih beberapa aspek penting, seperti koordinasi motorik, berpikir secara fleksibel, merencanakan, menerapkan strategi, mengubah perilaku, dan memonitor diri. Dalam memasak, diperlukan status informasi pada setiap hidangan, sehingga dapat memengaruhi memori kerja yang penting dalam pelaksanaan rencana memasak..$^{25}$ Hal ini juga menunjukkan bahwa kegiatan yang lebih kompleks seperti memasak berhubungan dengan fungsi kognitif yang lebih baik.

Faktor jenis aktivitas fisik (belanja) memiliki hubungan bermakna terhadap fungsi kognitif. Menurut penelitian Berezuk C dkk, bahwa individu yang melakukan Instrumental Activities of Daily Living (IADL) dapat mengembangkan cadangan fungsional yang lebih besar sehingga dapat memperlambat penurunan fungsi kognitif. Di dalam IADL terdapat jenis aktivitas belanja, maka faktor jenis aktivitas belanja dapat memengaruhi kognitif. ${ }^{26}$

Beberapa penelitian longitudinal menegaskan bahwa terdapat hubungan antara aktivitas fisik terhadap fungsi kognitif. ${ }^{27}$ Hal ini disebabkan karena aktivitas fisik dapat meningkatkan mRNA brainderived neurotrophic factor (BDNF) dan protein di hipokampus, serta bagian otak lainnya. ${ }^{28}$

Keterbatasan penelitian ini, tidak menanyakan penggunaan obat-obatan dan durasi serta derajat berat menderita hipertensi dan diabetes, sehingga memengaruhi hasil penelitian. Pada penelitian ini gangguan fungsi kognitif, dinilai hanya menggunakan instrumen MMSE, sehingga masih mungkin ada "ceiling effect" pada tingkat pendidikan di atas 9 tahun. 


\section{KESIMPULAN}

Usia merupakan faktor risiko penurunan fungsi kognitif, namun status perkawinan single/cerai/janda dan aktivitas fisik (memasak) merupakan faktor protektif terhadap penurunan fungsi kognitif pada lansia perempuan.

\section{DAFTAR PUSTAKA}

1. Kemenkes. Analisis lansia Indonesia. Jakarta. 2017.

2. Ji Y, Shi Z, Zhang Y, Liu S, Liu S, Yue W, dkk. Prevalence of dementia and main subtypes in rural Northern China. Dement Geriatr Cogn Disord. 2015;39(5-6):294-302.

3. Carnero-Pardo C. Should the mini-mental state examination be retired? Neurol Engl Ed. 2014;29(8):473-81.

4. Shi Z, Zhang Y, Yue W, Liu M, Huo YR, Liu S, dkk. Prevalence and clinical predictors of cognitive impairment in individuals aged 80 years and older in rural China. Dement Geriatr Cogn Disord. 2013;36(3-4):171-8.

5. Hara Y, Waters EM, McEwen BS, Morrison JH. Estrogen effects on cognitive and synaptic health over the lifecourse. Physiol Rev. 2015;95(3):785-807.

6. Ren L, Bai L, Wu Y, Ni J, Shi M, Lu H, dkk. Prevalence of and risk factors for cognitive impairment among elderly without cardio- and cerebrovascular diseases: a population-based study in rural China. Front Aging Neurosci. 2018;10:62-2.

7. Murray AD, Staff RT, McNeil CJ, Salarirad S, Ahearn TS, Mustafa N, dkk. The balance between cognitive reserve and brain imaging biomarkers of cerebrovascular and Alzheimer's diseases. Brain. 2011;134(Pt 12):3687-96.

8. Sommerlad A, Ruegger J, Singh-Manoux A, Lewis G, Livingston G. Marriage and risk dementia: systematic review and meta-analysis of observational studies. $\mathrm{J}$ Neurol Neurosurg Psychiatry. 2018;89(3):231-8.

9. Zulkifly MFM, Ghazali SE, Din CE, Subramaniam P. The influence of demographic, clinical, psychological and functional determinants on post-stroke cognitive impairment at day care stroke center, Malaysia. Malays J Med Sci. 2016;23(2):53-64.

10. Hebert LE, Scherr PA, Bennett DA, Bienias JL, Wilson RS, Morris MC, dkk. Blood pressure and latelife cognitive function change: a biracial longitudinal population study. Neurology. 2004;62(1):2021-4.

11. Wadley VG, McClure LA, Howard VJ, Unverzagt FW, Go RC, Moy CS, dkk. Cognitive status, stroke symptom reports, and modifiable risk factors among individuals with no diagnosis of stroke or transient ischemic attack in the Reasons for Geographic and Racial Differences in Stroke (REGARDS) study. Stroke. 2007;38(4):1143-7.

12. Gottesman RF, Schneider AL, Albert M, Alonso A, Bandeen-Roche K, Coker L, dkk. Midlife hypertension and 20-year cognitive change: the atherosclerosis risk in communities neurocognitive study. JAMA Neurol. 2014;71(10):1218-27.

13. Zilliox LA, Chadrasekaran K, Kwan JY, Russell JW. Diabetes and cognitive impairment. Curr Diab Rep. 2016;16(9):87.

14. Gottesman RF, Albert MS, Alonso A, Coker LH, Coresh J, Davis SM, dkk. Associations between midlife vascular risk factors and 25-year incident dementia in the Atherosclerosis Risk in Communities (ARIC) cohort. JAMA Neurol. 2017;74(10):1246-54.

15. Yasuno F, Tanimukai S, Sasaki M, Hidaka S, Ikejima C, Yamashita F, dkk. Association between cognitive function and plasma lipids of the elderly after controlling for apolipoprotein E genotype. Am J Geriatr Psychiatry. 2012;20(7):574-83.

16. Elias PK, Elias MF, Agustino RB, Sullivan LM, Wolf PA. Serum cholesterol and cognitive performance in the framingham heart study. Psychosom Med. 2005;67:24-30.

17. Anggara S, Putra YA, Widayanti JR, Turana Y, Handajani YS. Hiperkolesterolemia dan APOE genotip E4/E4 sebagai faktor risiko gangguan bahasa pada lanjut usia. Neurona. 2015;33(1):30-5.

18. Emmerzaal TL, KiliaanAJ, Gustafson DR. 2003-2013: a decade of body mass index, Alzheimer's disease, and dementia. J Alzheimers Dis. 2015;43(3):739-55.

19. Gustafson D, Lissner L, Bengtsson C, Bjorkelund C, Skoog I. 24-year follow-up of body mass index and cerebral atrophy. Neurology. 2004;63(10):1876-81.

20. Devanan DP, Pelton GH, Zamora D, Liu X, Tabert $\mathrm{MH}$, Goodkind M, dkk. Predictive utility of apolipoprotein E genotype for Alzheimer disease in outpatients with mild cognitive impairment. Arch Neurol. 2005;62(6):975-80.

21. Small BJ, Graves AB, McEvoy CL, Crawford FC, Mullan M, Mortimer JA. Is APOE4 $\varepsilon 44$ a risk factor for cognitive impairment in normal aging? Neurology. 2000;54:2082-8.

22. Yip AG, Brayne C, Easton D, Rubinstein DC. Apoliprotein E4 is only a weak predictor of dementia and cognitive decline in the general population. J Med Genet. 2002;39(9):639-43.

23. Chaudhari K, Sumien N, Johnson L, D'Agostino $\mathrm{D}$, Edwards M, Paxton RJ, dkk. Vitamin C supplementation, APOE4 genotype and cognitive functioning in a rural-dwelling cohort. J Nutr Health Aging. 2016;20(8):841-4.

24. Shalim CP, Rahadian, J, Turana Y. Efek pekerjaan 
rumah tangga dalam pencegahan penurunan fungsi kognitif pada lansia perempuan berpendidikan rendah. Neurona. 2017;35(1):31-5.

25. Cerasa A, Arcuri F, Pignataro LM, Serra S, Messina $\mathrm{D}$, Carozzo S, dkk. The cooking therapy for cognitive rehabilitation of cerebellar damage: a case report and a review of the literature. J Clin Neurosci. 2019;59:357-61.

26. Berezuk C, Zakzanis KK, Ramirez J, Ruocco AC, Edwards JD, Callahan BL, dkk. Functional reserve: experience participating in instrumental activities of daily living is associated with gender and functional independence in mild cognitive impairment. J Alzheimers Dis. 2017;58(2):425-34.

27. Blondel SJ, hammersley-Mather R, Veerman JL. Does physical activity prevent cognitive decline and dementia? a systematic review and metaanalysis of longitudinal studies. BMC Public Health. 2014;14(1):510.

28. Huang T, Larsen KT, Ried-Larsen M, Moller NC, Andersen LB. The effects of physical activity and exercise on brain-derived neurotrophic factor in healthy humans: a review. Scand J Med Sci Sports. 2014;24(1):1-10. 